\title{
Conceptual Approach to Cooperative Learning: Its Effect on the Learning of Conceptual Approach among the Pre-service Biology Teachers
}

\author{
Eng Tek Ong ${ }^{1}$, Charanjit Kaur Swaran Singh ${ }^{2, *}$, Yoon Fah Lay ${ }^{3}$, Tarsame Singh Masa Singh ${ }^{4}$, \\ Melor Md Yunus ${ }^{5}$

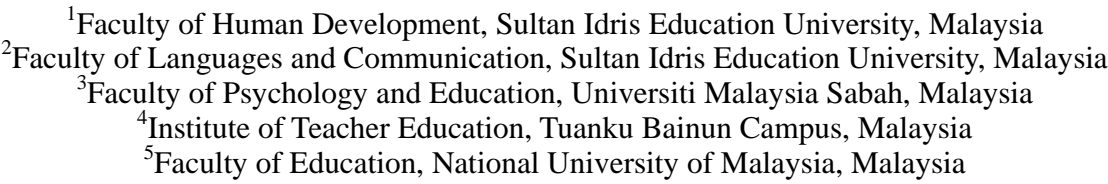

Received February 21, 2020; Revised March 23, 2020; Accepted March 28, 2020

Copyright $\odot 2020$ by authors, all rights reserved. Authors agree that this article remains permanently open access under the terms of the Creative Commons Attribution License 4.0 International License

\begin{abstract}
This study aims to establish the effectiveness of a Conceptual Approach in enhancing the learning of Conceptual Approach to cooperative learning among $274^{\text {th }}$ semester pre-service Biology teachers in science teacher education. Accordingly, the Conceptual Approach employed in this study entails the incorporation of its five essential elements, namely positive independence, individual accountability, group processing, social skills, and face-to-face interaction into the context of problem solving within a cooperative learning setting. The research design employed was that of a triangulation mixed-methods design which provides a fuller and deeper understanding of the phenomenon at hand. The quantitative method used was that of one-group pretest-posttest design whereby a pretest was administered before the intervention while the posttest was administered after the three-hour intervention. Meanwhile, the qualitative method involved the generation of lesson ideas incorporating the Conceptual Approach so as to illuminate what has been learnt by the pre-service Biology teachers. The findings indicate that the analysis of the pretest and posttest data using paired samples t-test yielded a t of -17.90 which was statistically significant $(\mathrm{p}<.001)$. The analysis of the qualitative data consisting of lesson ideas generated indicates that the pre-service Biology teachers had an adequate grasp in that they were able to incorporate, albeit at differing frequencies, the five essential elements of Conceptual Approach within the 5E Instructional Model. The results are discussed in terms of how the key findings relate to other studies and also in terms of the pedagogical approach germane for teacher education. Implications for future research are also delineated.
\end{abstract}

Keywords Conceptual Approach, Cooperative Learning, Teacher Education, Pre-service Biology Teachers, Malaysia

\section{Introduction}

The Malaysian society is renowned for "gotong royong", which means community self-help or mutual cooperation in which each member of a community lends his/her helping hands to complete a task which ranges from clearing a bushy area, cleaning up a school compound, to building a house for the poor in the name of brotherliness and a caring community. Cooperation is as relevant to the promotion of peace and harmony among people and nations as it is to the creation of a united Malaysian society and an industrialised nation. Accordingly, "cooperation" is one of the 12 stipulated "scientific attitudes and values" listed in the Malaysian science syllabuses Ministry of Education [1].

Gillies [2] advocates that the cooperative learning is one of the teaching strategies every teacher needs to have in their pedagogical repertoire. Such advocacy is based on previous findings which indicate the effectiveness of cooperative learning in promoting learning across educational levels (i.e., from pre-school, primary, secondary, pre-university, to tertiary level) and across disciplines (i.e., various subjects such as science and mathematics) [3-6].

There is a plethora of definitions on cooperative learning, 
and the definition provided by each proponent depends on his/her philosophical belief. Slavin [6] defines cooperative learning as "teaching methods in which students work together in small groups to help each other learn academic content. Mercer and Mercer [7] surmise that cooperative learning is a peer-mediated, instructional arrangement whereby "small groups or teams of students work together to achieve team success in a manner that promotes the students' responsibility for their own learning as well as the learning of others" (p. 35). Meanwhile, Johnson and Johnson [8] define cooperative learning as "the instructional use of small groups so that students work together to maximize their own and each other's learning" (p. 9). Jacobs, Power and Loh [9], by contrast, define cooperative learning as the "principles and techniques for helping students work together more effectively" (p. 1). Based on these definitions, it can be deduced that the defining characteristics of cooperative learning encompass but not are limited to the followings: teaching method and strategy, using of small groups or teams, helping each other, working together effectively, and mastering academic content.

There is a range of cooperative learning techniques which can be employed in the learning and facilitation of science to enhance students' understanding of the curriculum content. These cooperative learning techniques are generally subsumed under the umbrella of 3 major approaches, namely (1) The Conceptual Approach, (2) The Structural Approach, and (3) The Curricular Approach.

The Conceptual Approach or Circles of Learning, propounded by Johnson, Johnson, Holubec, and Roy [10] and was formerly known as Learning Together, is a five-element conceptually-based model which is not tied to any specific curriculum or subject area. The five elements, according to Putman [11] are: positive interdependence, individual accountability, face-to-face interaction, teaching of social skills, and group processing.

By contrast, the Structural Approach to cooperative learning, developed by Kagan [12] necessitates the use of a content-free structure which is defined as a way of organising social interaction in the classroom. Embodying all these content-free structures (i.e., RoundRobin, RallyRobin, RoundTable, RallyTable, Simultaneous Roundtable, and Timed-Pair-Share) are four basic principles: positive interdependence, individual accountability, equal participation, and simultaneous interaction.

Meanwhile, the Curricular Approach, which is also known as Student Team Learning variations was developed by Slavin [13]. Cooperative learning models subsumed under the Curricular Approach consists of Student Teams-Achievement Divisions or STAD [14,15], Teams-Games-Tournament or TGT [15,16], Jigsaw-II [15,17], Team Assisted Individualization or TAI [15,18], and Cooperative Integrated Reading and Composition or CIRC $[15,19]$. Embodying the successful implementation of these student team learning methods are team rewards, individual accountability and equal opportunities for success. Teams can earn team rewards if they achieve the upfront agreed-upon criteria for success. Individual accountability requires that each individual in the team must be accountable for his/her learning and the learning of his/her teammates, ensuring that the team will be successful. Equal opportunities for success mean that each student has an equal opportunity to succeed and contribute to his/her team by improving on his/her previous performance [13-15].

The review of the literature indicates that there is a solid body of research, including over 800 studies conducted over 25 years which establishes that cooperative learning indeed benefits students in a number of ways, ranging from the academic or cognitive realms to the realms of personal and social development $[6,8,20,21,22,23]$.

The review of the past literature on cooperative learning by approaches indicates that Curricular Approach which takes the form of student team learning methods such as STAD [24,25], Jigsaw-II [26,27], TGT [16,28,29,30] was found to be effective in enhancing learning and that the Structural Approach [31,32] was equally effective. Nevertheless, there is a scarcity of research on the effectiveness of Conceptual Approach. Such a scarcity could be due to the vagueness in terms of its actual classroom implementation, as there are no clear-cut steps like other cooperative learning methods. Hence there is need to concretise what Conceptual Approach entails for classroom implementation, particularly in pre-service teacher education and thereafter, to establish its effectiveness in pre-service teacher education. Accordingly, this research aims to answer the research questions: What are the effects of a Conceptual Approach to cooperative learning on the learning of Conceptual Approach among the pre-service Biology teachers?

While a more detailed description of each of the above-mentioned cooperative learning methods within the Curricular Approach as well as the Structural Approach is available in the corresponding accompanied references, the following subsection gives a brief description on conceptual approach as it is the cooperative learning approach which was employed in this study.

\section{Conceptual Approach to Cooperative Learning: A Review}

The first essential component for the Conceptual Approach is positive interdependence. When there is a positive interdependence, each member perceives that he/she can reach his/her learning goals if and only if the other members of his/her learning group also reach their goals [33-35]. Members of each group believe that they are linked with each other in the way one cannot succeed unless the other members in the group succeed (and vice 
versa), that is they "sink or swim together" (i.e., recognising all group members share a common fate). Group members are seen working together in ways that support one another's learning, striving for mutual benefit so that all group members benefit from each other's efforts (i.e., Your success benefits me and my success benefits you), realising that one's performance is mutually caused by oneself and one's group members (i.e., We cannot do it without you) and feeling proud and jointly celebrating when a group member is recognised and rewarded for achievement (i.e., You got an A! That is awesome).

There are many ways of structuring positive interdependence. For instance, positive goal interdependence is where each member completes a different part of the task, pooling their work into one final product when they are finished. In positive resource interdependence, group members share limited materials as opposed to a traditional group where every member has his/her resource and works independently within a group. According to Johnson and Johnson [34], resource positive interdependence is created by "giving each group one copy of the problem to be solved. All students work the problem on scratch paper and share their insights with each other" (p.4).

Positive role interdependence, on the other hand, is structured when each member is assigned a complementary and interconnected role. In a science lesson, to illustrate that, the following roles could be assigned. Summarizer-checker makes sure everyone in the group understands what is being learned; researcher-runner gets needed materials for the group and communicates with other learning groups and the teacher; recorder writes down the group's decisions and edits the group's report, encourager reinforces members' contributions, and observer keeps track of how well the group is collaborating.

The second component for Conceptual Approach is that of individual accountability which is realised when every group member is assessed and the feedback of his/her mastery of assigned materials (or result) on how each member is progressing is given back to the individual and the group so that other group members know whom to help and encourage. Every member has to learn and responsibly contribute to the work and success of the group. No free-rider student can hitchhike or thumb-ride or even "buy-out" of the group task and evade learning. Neither can there be any student taking control or monopolising the group task.

Telling group members that one of them will be called at random to answer or to share the group's view and having group members take individual test without group members' help at the end of a lesson are two of the many examples of structuring individual accountability. Johnson and Johnson [34] even suggest "giving an individual test to each student and randomly selecting one student's work to represent the efforts of the entire group" (p.4) to be one of the common ways of structuring individual accountability.

The third component or element of the Conceptual Approach is social skills which is largely assumed or rather ignored in normal traditional group work. This third component entails explicit or deliberate teaching of social skills, engaging in appropriate behaviour and employing germane language structures. "Taking turns to speak", "asking for help and giving help", "praising", "saying please/thank you" and "disagreeing without criticising people" are just a few examples of possible social skills that can be taught to students within the context of a cooperative environment.

Johnson and Johnson [34] emphatically advocate the explicit teaching of social skills because groups cannot function effectively if students are lacking the social skills which include the leadership, decision-making, trust-building, communication and conflict-management skills. These social skills have to be explicitly taught just as purposefully and precisely as academic skills.

Teachers should not assume that students have the social skills necessary to cooperate with other students given the fact that students come from a wide range of family background and that one's development of social skills is the function of influence from one's peer groups and family upbringing. Instead, teachers should teach the missing or undeveloped social skills and/or review and reinforce the crucial social skills that students need to learn cooperatively. Essentially, in teaching social skills, Ong and Yeam [36] propose that the students need to understand

i). why they are learning the skill;

ii). what the skill is, conceptually and behaviourally;

iii). ways the skill is practised; and

iv). how well they have used the skill and how they can improve their use of the skill.

The fourth component in the Conceptual Approach is group processing where group members are given time regularly, though not necessarily in every session, to evaluate how well their respective groups have functioned or worked previously, reflect on their interaction and the use of social skills, and plan how the group can work better the next time. There are many ways of structuring group processing, and one of the ways is by asking students in each group to reflect or answer these two questions: (1) What has each member in my group done that was helpful for the group?; and (2) What can each member in my group do to make the group even better tomorrow or in the next lesson when we learn in our cooperative learning group? Alternatively, these two questions could also be asked: (1) How have I enjoyed working in the group; and (2) How can we work more effectively in future (or in subsequent cooperative learning)? 
Such group processing not only enables members of every group to focus and improve on group maintenance, but also ensures that each group member receives feedback on his/her participation and improves on his/her contribution to the learning. To facilitate successful group processing, teachers should (1) ensure group members understood the expectations and the purposes of group processing; (2) allow sufficient time for the group processing to take place, refraining from rushing through the processing; (3) maintain student involvement in the processing, ensuring the voices of every group member is heard and noted; (4) remind students to use their social skills (i.e., active/polite listening) while group members process; and (5) require each group to turn in a summary of their processing that is signed by all the group members.

Finally, the fifth component for the Conceptual Approach is face-to-face interaction or, face-to-face promotive interaction if you like, that allows or promotes students to be actively engaged, stimulating communication and sharing of ideas or resources. To foster such a sense of involvement, belonging and commitment, students sit in a cluster of 2-4 members in the manner that is termed as a knee-to-knee or eye-to-eye position. Students promote each other's learning by orally explaining to each other to solve the given problems, discussing with each other the concepts, skills and strategies being learned, teaching their knowledge and skills to each other, and explaining to each other the connections of prior learning and current learning. While interacting and asking questions of each other, students use each other's names, eye contact and appropriate body language. Such face-to-face mode of sitting and interaction results in higher incidence of answers, ideas or explanations being generated and put forward, which will then be examined, justified or even be discarded by group members.

\section{Methodology}

\subsection{Research Design}

This study employed a mixed-methods design which, according to Creswell and Plano Clark [37], entails comparing, integrating, and interweaving quantitative and qualitative methods, thus providing a better understanding of the research problem and questions than either method by itself. More specifically, the triangulation mixed-methods design as depicted in Figure 1 was employed.

The triangulation of quantitative and qualitative data provides a fuller and deeper understanding of the phenomenon at hand -- in this case, the effect of the Conceptual Approach to cooperative learning on the learning of Conceptual Approach. Given the exploratory nature of this research (i.e., the novelty of carrying out such a research to determine the effect of the Conceptual Approach), the one-group pretest-posttest design was deemed appropriate. This design involved a single group that was pretested, exposed to a treatment and post-tested. While it is acknowledged that history and maturation were not controlled, the relatively short period of time (e.g., 3-hour intervention programme) would likely to ameliorate these threats to internal validity. To triangulate the quantitative data, qualitative responses in terms of written responses in the form of individual self-reflection and groups' science lesson ideas which incorporated the Conceptual Approach were gathered so as to illuminate what has been learnt by the participants.

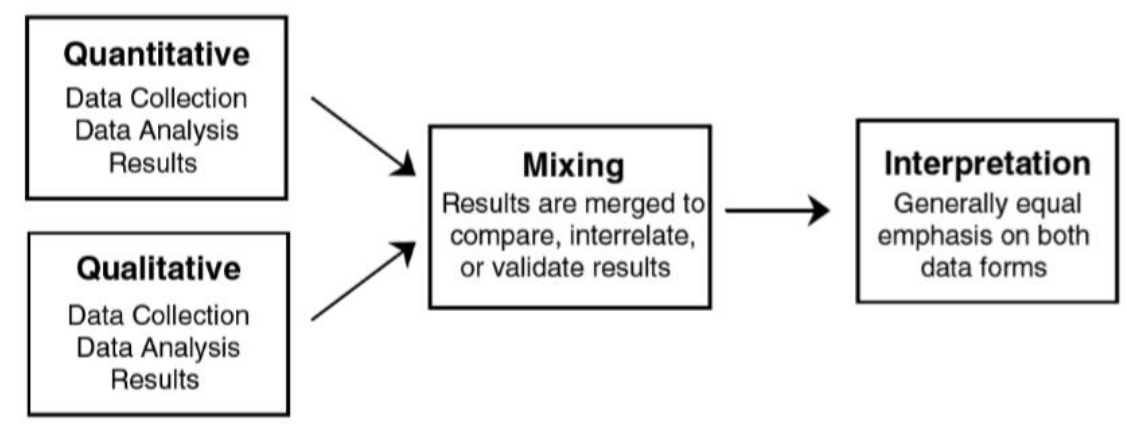

Source: Creswell and Plano Clark [37]

Figure 1. Triangulation Mixed-Methods Design 


\subsection{Sampling}

The participants of this research comprised a total of 27 $4^{\text {th }}$-semester pre-service Biology teachers (4 males and 23 females) at one higher institution. These pre-service teachers followed the course on "Teaching, Technology and Assessment 1", officially coded as KPD3016, which familiarizes them essentially to the various science teaching methods, the use of technology in the teaching and learning, and the various forms of classroom assessments.

\subsection{Instrumentation}

The pretest and posttest developed by the researchers are basically the same 21-item test that aims to gauge the extent to which pre-service teachers possess the relevant knowledge about the Conceptual Approach. For example, a collective of items measures one's knowledge about (i) the three patterns of interaction (i.e., competitive, individualistic and cooperative), (ii) types of interdependence and each of their corresponding evaluation criterion, (iii) the five essential basic elements or components for Conceptual Approach, and (iv) the ability to match a situation to that of its corresponding basic component. Meanwhile, the internal consistency reliability of this pretest (as well as posttest), established by using Kuder-Richardson 20 (KR-20) with a sample of 13 pre-service teachers in another higher institution, was found to be at 0.81 , indicating an acceptable level of internal reliability and achieving more than the minimum level of 0.70 recommended [38,39].

\subsection{Data Gathering Procedures}

The 3-hour session on Conceptual Approach to cooperative learning was conducted at a microteaching room. Basically, the pre-service Biology teachers who acted as "students" followed through a simulation lesson on Conceptual Approach whereby they were asked to solve four problems in the problem-solving worksheet in their respective cooperative learning groups, each consisting of not more than four members. Prior to working in groups, students were assigned roles (i.e., structuring positive role interdependence) and were given 2 problem-solving worksheets in each group of four (i.e., structuring resource positive interdependence). Additionally, they were seated in the knee-to-knee and eye-to-eye position (i.e., structuring face-to-face promotive interaction), and were explicitly taught to say "thank you" when help is received (i.e., structuring social skills).

Figure 2 depicts the enactment of positive interdependence and face-to-face interaction. Additionally, group members were told to make sure everyone in the group learns and be able to solve each of the problems because a group member would be called at random to represent his/her group in explaining to the class (i.e., structuring individual accountability). At the end of the session, each group was asked to reflect what went well during the cooperative learning and what could be improved (i.e., group processing). When the whole activity has been debriefed in terms of the elements of the Conceptual Approach, in their respective groups, the pre-service Biology teachers were asked to plan a lesson sequence/idea in Biology which incorporates the elements of the Conceptual Approach.

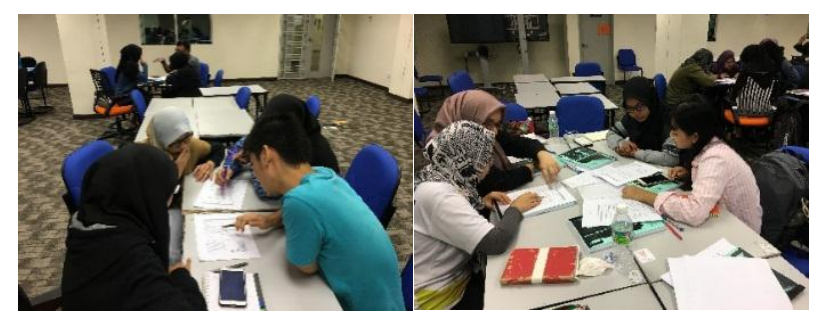

Figure 2. Positive Interdependence (i.e., Resource, Role) and Face-to-face Interaction (i.e., Seated in the knee-to-knee and eye-to-eye position)

\section{Results}

\subsection{Quantitative Analysis}

As shown in Table 1, the t-test for paired samples yielded a t of -17.90 which was statistically significant (p $<.001$ ) and a "high" effect size of +3.45 that was educationally significant. The mean score obtained in the posttest (55.19) was statistically significantly higher than the mean score obtained for the pretest $(0.00)$. Therefore, the posttest mean score for the group of 27 pre-service Biology teachers shows an appreciably higher degree of knowledge in Conceptual Approach than their pretest mean score.

Table 1. Results Obtained from t-test for Paired Samples

\begin{tabular}{|c|c|c|c|c|c|c|c|c|}
\hline \multicolumn{3}{|c|}{ Pretest } & \multicolumn{3}{|c|}{ Posttest } & \multirow[b]{2}{*}{$\mathrm{t}$} & \multirow[b]{2}{*}{$\mathrm{p}$} & \multirow[b]{2}{*}{$\Delta^{+}$} \\
\hline $\mathrm{N}$ & Mean & SD & $\mathrm{N}$ & Mean & SD & & & \\
\hline 27 & 0.00 & 0.00 & 27 & 55.19 & 16.02 & -17.90 & .000 & +3.45 \\
\hline
\end{tabular}




\subsection{Qualitative Analysis}

As pointed out earlier, this research employs the triangulation mixed-methods design in which the quantitative data will be triangulated by the qualitative data. The results of the analysis of qualitative data are provided below.

The analysis of the prepared lesson ideas from all the cooperative learning groups indicates that the pre-service Biology teachers had an adequate grasp of the Conceptual Approach to cooperative learning. Because all the five essential elements, namely positive interdependence, individual accountability, group processing, explicit teaching of social skills, and face-to-face interaction were incorporated in their lesson ideas, although these lesson ideas differed in the ways in which these elements were incorporated. For instance, a group exemplifies positive interdependence by means of sharing resources such as worksheets (i.e., resource positive interdependence) while another group structures positive interdependence by means of assigning roles to the group members (i.e., role positive interdependence). Yet another group exemplifies a combination of resource as well as role positive interdependence.

In exemplifying the qualitative analysis, the lesson idea from a group consisting of 4 members (i.e., Amira, Nazihan, Suzica and Shazrizal) is used for discussion. Its content coverage of a biological concept on the structure of a plasma membrane according to the prescribed Curriculum Specification for Biology Form 4 by Curriculum Development Division [40] is shown in Table 2. Meanwhile, Table 3 summarises a typical lesson idea which shows the integration of the elements of the Conceptual Approach into the 5E's Instructional Model propounded by Bybee and Landes [41] which entails the phases of Engagement, Exploration, Explanation, Elaboration/Expansion, and Evaluation. Such an integration is prominently highlighted by underlining the elements in the "Remark" column which match with their corresponding teaching and learning activities.

Table 2. Curricular Content Coverage for Structure of a Plasma Membrane

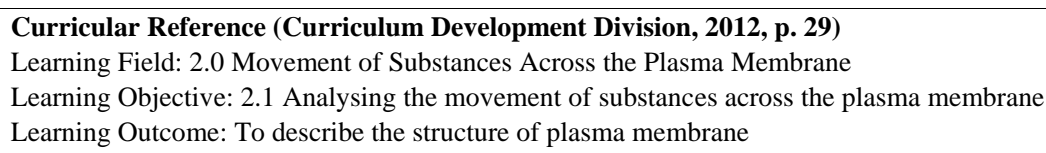

\title{
Scientific Facts:
}

1. According to the fluid-mosaic model by S.J. Singer and G.J. Nicholson, plasma membrane consists of protein and phospholipid.

2. A molecule of a phospholipid consists of two sections: The polar head which is hydrophilic, and the non-polar tails which are hydrophobic as shown in the following diagram.

\section{Polar head which is} hydrophilic

\author{
Non-polar tails \\ consisting of \\ hydrocarbon chains \\ which are \\ hydrophobic
}

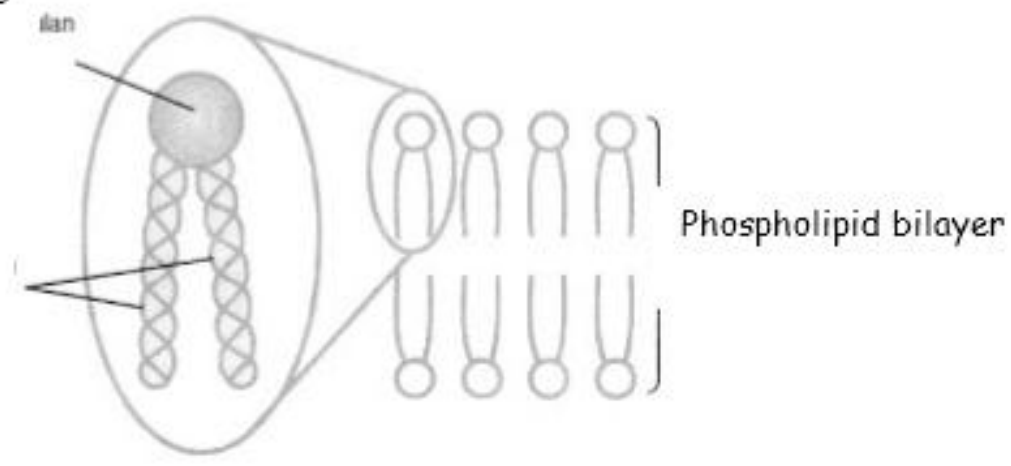

3. A plasma membrane consists of a phospholipid bilayer. The heads of the phospholipid molecules at outer layer face the fluid in the outer environment or extracellular space, while the heads of the phospholipid molecules in the inner layer face towards the intracellular space which includes cytoplasm. Meanwhile, the tails of each phospholipid form the bilayer which faces each other.

4. The phospholipid bilayer acts as a barrier or membrane between the interstitial fluid and intracellular fluid.

5. There are various types of protein molecules which are spread between the phospholipid bilayer. The protein molecule which forms a pore or canal are termed as protein pore or protein channel, while the protein molecule which functions as the carrier is called the carrier protein.

6. Certain protein and lipid which have carbohydrate chains bound to their outer surfaces are known as glycoprotein and glycolipid respectively. 
7. Phospholipid bilayer also contains cholesterol which hold the fatty acids. Cholesterol stabilises and strengthens the plasma membrane, making it more flexible but less permeable to water-soluble materials such as ions. Without cholesterol, plasma membrane will be too fluid at body temperature and will probably break or decompose.

8. The two diagrams embedded in Table 2 show the structure of a plasma membrane.

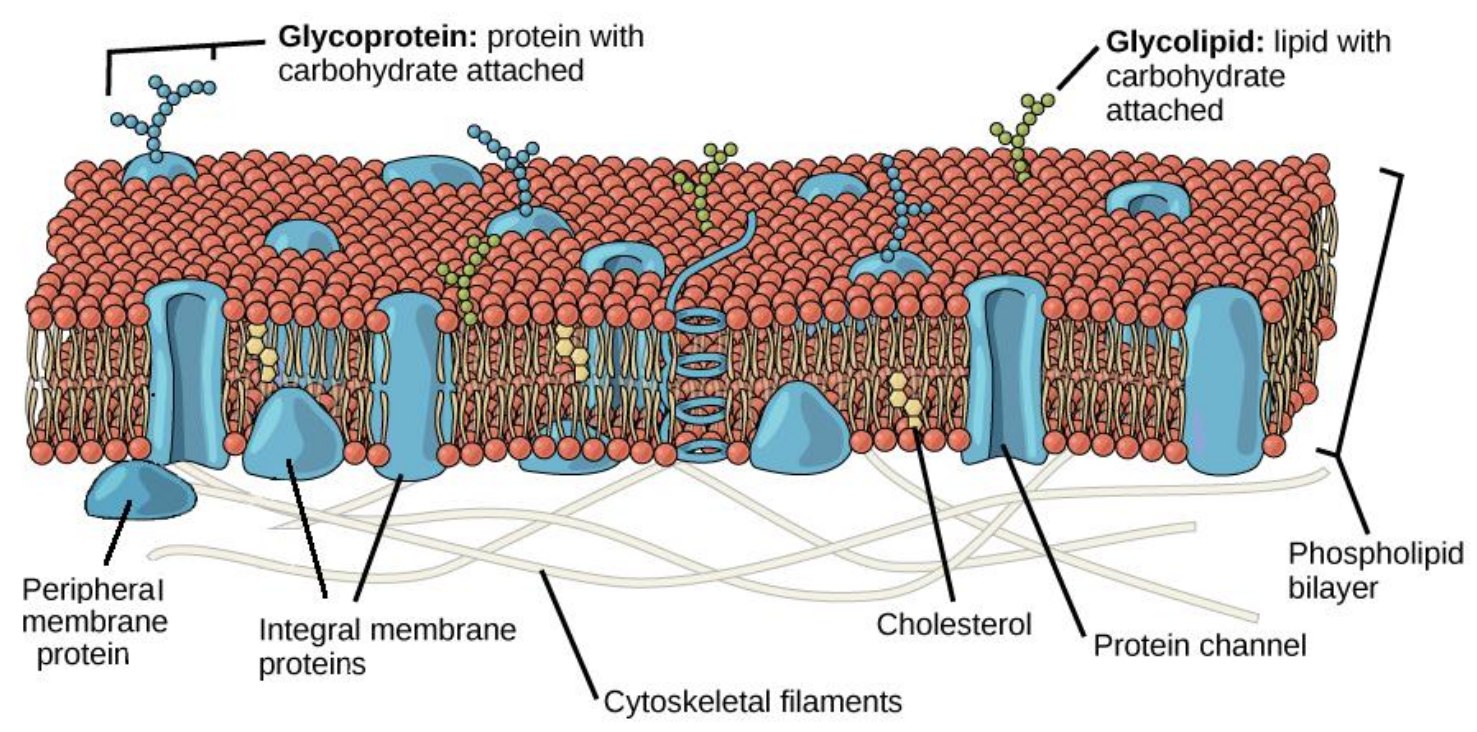

Source: https://www.khanacademy.org/science/high-school-biology/hs-cells/hs-the-cell-membrane/a/structure-of-the-plasma-membrane

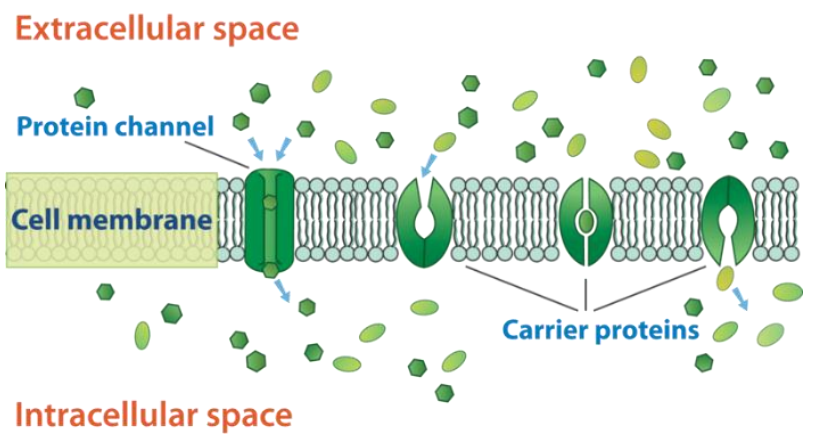

Source: https://www.ck12.org/book/CK-12-Biology/section/3.3/ 
Table 3. Integration of the elements of a Conceptual Approach into the 5E's Instructional Model

\begin{tabular}{|c|c|c|}
\hline Phase & Teaching and Learning Activities & Remark \\
\hline \multirow[b]{2}{*}{ Engage } & $\begin{array}{l}\text { Teacher shows the movement of substances across a plasma membrane at the } \\
\text { following URL } \\
\text { https://www.youtube.com/watch?v=_VqL6Ppa8eg }\end{array}$ & \\
\hline & $\begin{array}{l}\text { Based on the short video clip, students, in groups of four, are asked to draw the } \\
\text { structure of a plasma membrane and label the following parts: } \\
\text { - Phospholipid bilayer } \\
\text { - Carrier proteins } \\
\text { - Protein pores/channels }\end{array}$ & $\begin{array}{l}\text { Face-to-face Interaction: } \\
\text { Students are seated around a table in an } \\
\text { eye-to-eye and knee-to-knee position. }\end{array}$ \\
\hline Explore & $\begin{array}{l}\text { Students are asked to check their initial drawing of a plasma membrane against } \\
\text { the drawing provided in the textbook / Internet / other relevant resources. } \\
\text { Teacher reminds students that they have to make sure each member knows the } \\
\text { name of each part of a plasma membrane structure because a member would be } \\
\text { called at random to represent the group to answer. }\end{array}$ & $\begin{array}{l}\text { Positive Interdependence: } \\
\text { The following roles are assigned: } \\
\text { i). Recorder } \\
\text { ii). Time keeper } \\
\text { iii). Runner } \\
\text { iv). Encourager }\end{array}$ \\
\hline Explain & $\begin{array}{l}\text { In turn, one student from each of the groups is called to describe and to label the } \\
\text { following parts of and around the structure of a plasma membrane: } \\
\text { - Phospholipid with polar head and non-polar tails } \\
\text { - Phospholipid bilayer } \\
\text { - } \quad \text { Protein Channel } \\
\text { - } \quad \text { Interstitial fluid } \\
\text { - Intercellular fluid } \\
\text { - Glycoprotein } \\
\text { - Glycolipid }\end{array}$ & $\begin{array}{l}\text { Individual Accountability: } \\
\text { Anyone in a group would be called at } \\
\text { random. }\end{array}$ \\
\hline \multirow[b]{2}{*}{$\begin{array}{l}\text { Expand or } \\
\text { Elaborate }\end{array}$} & $\begin{array}{l}\text { Teacher gathers all group members, merging them as a big group to perform a } \\
\text { role play. As they merge, teacher asks students to greet one another by saying, } \\
\text { "Hello, and good morning". }\end{array}$ & $\begin{array}{l}\text { Social Skills: } \\
\text { Explicit teaching of greeting a friend. }\end{array}$ \\
\hline & $\begin{array}{l}\text { Teacher assigns each student to one of the following pertinent roles with a } \\
\text { corresponding tag: } \\
\text { - } \quad \text { Protein channel/pore } \\
\text { - } \quad \text { Carrier Protein } \\
\text { - Phospholipid bilayer } \\
\text { - Molecules }\end{array}$ & $\begin{array}{l}\text { Positive Interdependence: } \\
\text { Each student is assigned a role in the } \\
\text { role-playing }\end{array}$ \\
\hline \multirow{3}{*}{ Evaluate } & $\begin{array}{l}\text { Teacher directs students to individually answer the questions posed in their } \\
\text { textbook on page } 50 \text {. When everyone has answered the questions, teacher } \\
\text { checks the answer to each question by calling a student at random. }\end{array}$ & $\begin{array}{l}\text { Individual Accountability: } \\
\text { Students individually answer the } \\
\text { questions. } \\
\text { Students are called upon at random. }\end{array}$ \\
\hline & $\begin{array}{l}\text { In their respective groups, students are asked to reflect on the question: What } \\
\text { went well in our group today, and what can be improved should we learn } \\
\text { together in the next lesson? }\end{array}$ & $\begin{array}{l}\text { Group Processing: } \\
\text { Students make a reflection on what went } \\
\text { well and what could be improved. }\end{array}$ \\
\hline & $\begin{array}{l}\text { At the end of the class, teacher encourages students to thank every member in } \\
\text { their respective groups. }\end{array}$ & $\begin{array}{l}\text { Social Skills: } \\
\text { Explicit teaching of saying "thank you". }\end{array}$ \\
\hline
\end{tabular}




\section{Discussion}

This study uses the triangulation mixed-methods to gauge if the learning of Conceptual Approach among a group of 27 pre-service Biology teachers by means of Conceptual Approach to cooperative learning is indeed effective. The analysis of pretest and posttest data using paired samples t-test indicates that the attainment was markedly significant. Additionally, the triangulation from the analysis of qualitative data indicates that the pre-service Biology teachers were able to integrate the elements of the Conceptual Approach within their lesson plans, despite the fact that the lesson plans were basically the teaching sequence which followed the five phases of the $5 \mathrm{E}$ Instructional Model. In short, despite the limitations in sampling and intervention duration, the Conceptual Approach to cooperative learning has positively and significantly impacted on the knowledge on the use of Conceptual Approach to cooperative learning as evidenced in the findings from the analyses of quantitative as well as the qualitative data.

A literature search failed to locate any previous studies on the learning of Conceptual Approach by means of Conceptual Approach to cooperative learning in teacher education in general, and in Biology Education in particular. Accordingly, the findings of this study could not be directly compared. Hence, this explains the novelty and distinctiveness of this research project in terms of using Conceptual Approach as the pedagogical approach in learning about Conceptual Approach to cooperative learning.

The findings of this study were derived from the $4^{\text {th }}$-semester pre-service Biology teachers and there was no comparison group involved because of its limited generalizability. Further studies investigating similar impact of Conceptual Approach using a comparison group and a more representative sample at the University are recommended in order to examine the validity of such generalization.

While the lesson plans/ideas generated by the pre-service Biology teachers which integrated the essential elements of Conceptual Approach into the 5E Instructional Model seem to be interesting and pedagogically relevant, these lesson ideas have yet to be trialled and validated with students in an authentic, real-life school context to determine their effectiveness and for further adoption/adaptation by other school teachers. As such, it is strongly recommended that these lesson ideas could be trialled, validated and refined. By doing so, more research-based lesson plans could be added into the compendium of resources in Biology teaching for the benefits of the teachers and students.

Although this study was conducted with the pre-service teachers, it has an important implication for in-service professional development in terms of how it should be conducted to harness the effectiveness of in-service training. The way in which this study was conducted parallels the recommendation by Ong et al.[42] who strongly advocated for modelling the model where the facilitator should teach a particular teaching model through the use of the model itself. Such a method is also promoted by Loughran and Berry[43] who maintained that participants would get a better grasp of the theoretical and practical aspects of a pedagogical model if the educator or facilitator were able to explicitly model that particular teaching or pedagogical model for their participants, "the thoughts and actions that underpin one's pedagogical approach" (p. 193). Modelling the model is akin to being actively engaged in the learning. Being actively engaged during an in-service professional development has clear support from previous research findings [43-45] in which it affects the positive impacts of professional development programs.

\section{Conclusions}

This study which establishes the effectiveness of the use of Conceptual Approach to teach Conceptual Approach to cooperative learning in science teacher education among pre-service Biology teachers reveals one likely contributing factor in which the teaching of a particular pedagogical approach in teacher education should not be theoretical in nature. Instead, the teaching should be hands-on, that leads to minds-on which, taken as a whole, inculcates hearts-on - the love for such a pedagogical approach in addition to the knowledge of what and how such a pedagogical approach is enacted in the classroom. This resonates the advocacy by Ong et al.[42] in which the providence of each pedagogical approach, model, strategy or technique in teacher education "must be conducted in line with the practise-what-you-preach idiom and the maxim of modelling the practices that one expects of his/her pre-service teachers" (p. 397).

\section{Acknowledgements}

We acknowledge with great appreciation the kind gesture of the Research Management and Innovation Centre (RMIC) of Sultan Idris Education University for providing us with the NRGS Action Research Project Grant (Coded: 2018-0199-106-82). This NRGS (Niche Research Grant Scheme) Action Research Project Grant subsumes under a wider research grant, namely the NRGS (Coded: 2014-0001-107-82-2) entitled "Developing and Validating a Teaching and Learning Framework for Preparing Quality Teachers for the Future", of which the funding comes from the Higher Education Department, Ministry of Education, Malaysia. Equally, we would like to express our gratitude to the participating pre-service Biology teachers for their willing consent to participate in this research.

\section{REFERENCES}

[1] Ministry of Education. Secondary School Standard 
Curriculum for Form 3 Science: Curriculum and Assessment Document Standard, Malaysian Ministry of Education, Putrajaya, 2017.

[2] R. M. Gillies. (2016). Cooperative learning: Review of research and practice, Australian Journal of Teacher Education, Vol.41, No.3, 39-54, 2016.

[3] D. Johnson, R. Johnson, C. Roseth, T. Shin. The relationship between motivation and achievement in interdependent situations, Journal of Applied Social Psychology, Vol.44, No.9, 622-633, 2014.

[4] C. Roseth, D. Johnson, R. Johnson. Promoting early adolescents' achievement and peer relationships: The effects of ooperative, competitive, and individualistic goal structures, Psychological Bulletin, Vol.134, No.2, 223-246, 2008.

[5] R. Slavin. 2013. Effective programmes in reading and mathematics: Evidence from the Best Evidence Encyclopaedia, School Effectiveness and School Improvement, Vol.24, No.4, 383-391, 2013.

[6] R. Slavin. Cooperative learning and academic achievement: Why does groupwork work?, Anales De Psicologia, Vol.30, No.3, 785-791, 2014.

[7] C. D. Mercer, A. R. Mercer. (1998). Teaching Students with Learning Problems $\left(5^{\text {th }}\right.$ edn.), Prentice Hall, New Jersey, 1998.

[8] D. W. Johnson, R. T. Johnson. Learning together and alone (5th ed.), Allyn \& Bacon, Boston, 1999.

[9] G. M. Jacobs, M. A. Power, M.A., W. I. Loh. (2002). The teacher's sourcebook for cooperative learning: Practical techniques, basic principles, and frequently asked questions, Corwin Press, California, 2002.

[10] D. W. Johnson, R. T. Johnson, E. J. Holubec, D. Roy, D. (1984). Circles of Learning, Association for Supervision and Curriculum Development, Virginia, 1984.

[11] J. Putman. Cooperative Learning and Strategies for Inclusion, Brookes, London, 1998.

[12] S. Kagan. Cooperative learning. Kagan Cooperative Learning, California, 1992.

[13] R. E. Slavin. Using Student Team Learning ( $3^{\text {rd }}$ ed.), Johns Hopkins University, Maryland, 1986.

[14] R. E. Slavin. R.E. Student teams and achievement divisions, Journal of Research and Development in Education, Vol.12, No.1, 39-49, 1978.

[15] R. E. Slavin.. Using Student Team Learning (4 ${ }^{\text {th }}$. ed.), Johns Hopkins University, Maryland, 1994.

[16] D. L. DeVries, R. E. Slavin. Teams-Games-Tournament (TGT): Review of ten classroom experiments, Journal of Research and Development in Education, Vol.12, No.1, 28-38, 1978.

[17] R. E. Slavin. Using student team learning, John Hopkins University, Maryland, 1980

[18] R. E. Slavin, M. B. Leavey, N. A. Madden. (1986). Team Accelerated Instruction: Mathematics. Charlesbridge, Massachusetts, 1986.

[19] N. A. Madden, R. E. Slavin, R. J. Stevens. Cooperative Integrated Reading and Composition: Teacher's Manual. John Hopkins University, Baltimore, 1986.
[20] D. W. Johnson, R. T. Johnson, R.T. Learning together and alone: Overview and meta- analysis, Asia Pacific Journal of Education, Vol.22, No.1, 95-105, 2002.

[21] D. W. Johnson, G. Maruyama, R. T. Johnson, D. Nelson, L. Skon. Effects of cooperative, competitive, and individualistic goal structures on achievement: A meta-analysis, Psychological Bulletin, Vol.89, No.1, 47-62, 1981.

[22] R. E. Slavin. Cooperative learning and student achievement, Educational Leadership, Vol.46, No.2, 31-33, 1988.

[23] R. E. Slavin, C. Lake, P. Hanley, A. Thurston. Experimental evaluations of elementary science programs: A best-evidence synthesis, Journal of Research in Science Teaching, Vol.51, No.7, 870-901, 2014

[24] E. T. Ong, The effect of cooperative learning on the mathematics achievement of Form 4 students in a Malaysian secondary school, Journal of Science and Mathematics Education in Southeast Asia, Vol.22, No.2, 44-67, 1998

[25] B. Siti Maisarah, E. T. Ong, S. Mohd Zikri. (2018). The effectiveness of STAD (Student Teams-Achievement Division) cooperative learning method on the achievement of Islamic Religious Education, Paper presented at the $8^{\text {th }}$ UPI-UPI International Conference, October 8, Grand Tjokro Hotel, Bandung, Indonesia, 2018.

[26] W. Y. Chan, E. T. Ong, M. S. Sabri. M.S. The use of Jigsaw in primary science: What do year 5 children say about its influence on attitudes towards science?, Malaysian Journal of Science and Mathematics Education, Vol.6, No.2, 32-43, 2016.

[27] E. T. Ong, C. Y. Yeo. The effectiveness of Jigsaw-II cooperative learning method on student chemistry achievement, interest, interaction level, and attitudes, Malaysian Journal of Science and Mathematics Education, Vol.1, No.1, 46- 61, 2011.

[28] L. Juwita, N. P. W. Purnama Sari, Y. Septianingrum, Y. The effect of Team Game Tournament (TGT) cooperative learning method application towards learning motivation and achievement, Jurnal INJEC, Vol.2, No.2, 154-163, 2017.

[29] H. Mudiyanto. Differences of effectiveness of cooperative learning model type Teams-Games-Tournament (TGT) and group working on learning result at elementary school, Journal of Elementary Education, Vol.1, No.1, 25-36, 2017.

[30] A. Salam, A. Hossain, A. S. Rahman. (2015). Effects of using Teams Games Tournaments (TGT) cooperative technique for learning Mathematics in secondary schools of Bangladesh, Malaysian Online Journal of Educational Technology, Vol.3, No.3, 1-11, 2015.

[31] E. T. Ong, S. C. Tan. The effectiveness of Numbered Heads Together on Biology achievement among undergraduates at Sultan Idris Education University, Jurnal Teknologi, Vol.53, No.1, 35-46, 2010.

[32] S. C. Tan, E. T. Ong, P. E. S. Ong, The effectiveness of Numbered-Heads-Together cooperative learning method on Biology achievement among Form 4 students. Tempawan Jurnal Penyelidikan (Research Journal of Specialist Teachers' Education Institute), Vol.30, No.1, 24-33, 2013.

[33] M. Deutch. Cooperation and trust. Some theoretical notes, In M.R. Jones (Ed.), Nebraska symposium on motivation (pp. 275-319), University of Nebraska Press, Nebraska, 1962. 
[34] D. W. Johnson, R. T. Johnson. Cooperative learning. Innovacion Education Gobierno De Aragon, España, 2017.

[35] D. W. Johnson, R. T. Johnson, E. J. Holubec, Cooperation in the classroom $\left(9^{\text {th }}\right.$ ed.), Interaction Book Company, Minnesota, 2013.

[36] E. T. Ong, K. P. Yeam. The teaching of social skills in cooperative learning. Classroom Teacher, Vol.5, No.2, 41-49, 2000.

[37] J. W. Creswell, V. L. Plano Clark. (2007). Designing and conducting mixed methods research. Sage, California, 2007.

[38] J. O. Nunnally (1978). Psychometric theory, McGraw Hill, New York, 1978.

[39] D. A. DeVaus. Surveys in social research (4 ${ }^{\text {th }}$ ed.), Routledge, London, 2001.

[40] Curriculum Development Division. Secondary School Standard Curriculum Biology Form $4 \& 5$, Ministry of Education, Malaysia, 2018.

[41] R. Bybee, N. M. Landes. Science for life and living: An elementary school science program from Biological Sciences Improvement Study (BSCS), The American Biology Teacher, Vol.52, No.2, 92-98. 1990.

[42] E. T. Ong, C. K. Swaran Singh, N. Abd Rahman, L. M. Md Ibharim. (2019). The Character of Biology Teaching Practices: Pedagogical Hiatuses and the Implications for Continued Professional Development, The Journal of Social Sciences Research, Vol.5, No.2, 389-399, 2019.

[43] J. Loughran, A. Berry, A. Modelling by teacher educators, Teaching and Teacher Education, Vol.21, No.2, 193-203, 2005.

[44] D. Cohen, H. Hill. Instructional policy and classroom performance: The Mathematics reform in California, Teachers College Record, Vol.102, No.2, 294-343, 2000.

[45] D. Hawley, L. Valli, L. The essentials of effective professional development: A new consensus, In $\mathrm{L}$. Darling-Hammond \& G. Sykes (Eds.), Teaching as the Learning Profession. Handbook of Policy and Practice. (pp. 127-150), Jossey-Bass Publishers, San Francisco, 1999.

[46] L. Ingvarson, M. Meiers, A. Beavis. Factors affecting the impact of professional development programs on teachers' knowledge, practice, student outcomes \& efficacy, Education Policy Analysis Archives, Vol.13, No.10, 1-28, 2005. 